\title{
In situ electrochemical study of the interaction of cells with thermally treated titanium
}

\author{
L. Burgos-Asperilla \\ Department of Applied Physical Chemistry. Universidad Autónoma de Madrid. 28049 Madrid, Spain \\ J.L.G. Fierro \\ Institute of Catalysis and petroleochemistry, CSIC, Cantoblanco, 28049 Madrid, Spain.
}

\section{Gamero}

Department of Applied Physical Chemistry. Universidad Autónoma de Madrid. 28049 Madrid, Spain

\section{M.L. Escudero}

Department of Surface Engineering, Corrosion and Durability. National Centre for Metallurgical Research CENIM, CSIC, 28040 Madrid, Spain.

\section{Alonso}

Department of Applied Physical Chemistry. Universidad Autónoma de Madrid. 28049 Madrid, Spain.

$$
\text { M.C. García-Alonso }{ }^{\text {b) }}
$$

Department of Surface Engineering, Corrosion and Durability. National Centre for Metallurgical Research CENIM, CSIC, 28040 Madrid, Spain.

\section{${ }^{\text {b)} E l e c t r o n i c ~ m a i l: ~ c r i s g a @ c e n i m . c s i c . e s ~}$}

A modificar. In this study a $\mathrm{TiO}_{2}$ layer with surface nano roughness has been obtained by thermal treatment (TT-Ti) with the aim of increasing the corrosion resistance of titanium surfaces and improving the response of osteoblasts. The corrosion behavior of the $\mathrm{TiO}_{2}$ layer in the presence of osteoblastic Saos-2 cells has been examined over time using electrochemical techniques such as Electrochemical Impedance Spectroscopy (EIS) and polarization curves. The oxidized titanium surfaces were characterized by Scanning Electron Microscopy (SEM), Atomic Force Microscopy (AFM) and X-ray Photoelectron Spectroscopy (XPS). The effect of osteoblast cells on the electrochemical response of TT-Ti was clearly seen from the third day of testing with two time constants that were associated 
with the presence of Saos-2 cells and the TT-Ti oxide layer, respectively. Polarization curves show that the cells altered the overall resistance of the TT-Ti surfaces, enhancing anodic density current of the surface along culture time. XPS reveals the presence of proteins on the surface of the treated specimens in contact with the cells. A reduction in the thickness and the properties of the $\mathrm{TiO}_{2}$ layer is detected due to cellular activity.

The influence of cells on the electrochemical interface and the protectiveness of the $\mathrm{TiO}_{2^{-}}$ grown at low temperatures. 


\section{INTRODUCTION}

$\mathrm{Ti}$ and its alloys show an excellent corrosion resistance and biocompatibility which are attributed primarily to the naturally grown, dense and stable $\mathrm{TiO}_{2}$ on titanium -based surface $^{1,2}$. However, the mechanical properties of the passive film are poor. Ti-based materials have the lowest wear resistance of all metallic biomaterials used in biomedical applications. The continuous micro motion and fretting wear between bone and Ti-based alloys in stem and dental implants breaks the passive film and exposes the metal to the action of the complex surrounding medium generating substantial amounts of debris and a continuous Ti ion release. This process progresses on the surface of material attaching to the surrounding tissue little by little for many years incurring to the implant failure at longer implantation times ${ }^{3}$.

Various types of surface modifications are developed to improve the mechanical properties of the surface of $\mathrm{Ti}$ and its alloys and so the corrosion resistance and biocompatibility properties, including ion implantation ${ }^{4}$, thermo-mechanical processing ${ }^{5}$, oxidation $^{6,7}$, chemical methods and hydrothermal deposition of hydroxyapatite ${ }^{8,9}$. All of them have advantages and drawbacks associated with cost ineffectiveness between others, and most importantly, unreliably weak coating/substrate adhesion during service.

The surface modification of Ti-based alloys by thermal oxidation promotes the formation of grown-oxide layers of higher wear resistance and improved biocompatibility $^{10,11,12,13}$. The thermal treatment of different Ti alloys in air between 500-800 ${ }^{\circ} \mathrm{C}$ has been used to generate highly corrosion-resistant and biocompatible surfaces for implant applications ${ }^{14,15,16,17,18,19}$ in physiological fluids and in contact with live cell. Studies 
have been focused on controlling the structure of the crystal phase to obtain anatase-rich titanium dioxide and rutile-rich titanium dioxide on Ti alloy surfaces ${ }^{20,21}$.

The use of lower oxidation temperatures has been reported that can have a beneficial effect on the formation of hydroxyl groups that cover the surface to act as covalent bonds between organometallic compounds with the body physiological medium and living organisms and the oxidized titanium surface, increasing the stability of functional organic overlayers $^{22}$. The oxidation treatment at lower temperatures also has the advantage that minimal microstructural changes can be induced as a consequence of temperature. Lu et $^{23}$ found that the maximum oxidation of a Ti surface (in an oxygen-rich atmosphere) and the maximum $\mathrm{OH}$ concentration (in a water vapor-rich atmosphere) were achieved between 227$327^{\circ} \mathrm{C}$.

Most of the research published in literature analyses the biocompatibility of the biomaterial from the biochemical response offered by the cells. The interfacial characterizations between the cells and biomaterial are generally evaluated using the optical and/or electron microscope after fixing and dehydrating the cells cultured on the surface of the biomaterial ${ }^{21}$. However, the "in situ" study regarding the interfacial behaviors of the cells/biomaterial is limited in the literature.

Once the implanted material is inserted into the body, its surface is exposed to body fluids, such as intercellular fluid and blood depending on the surrounding tissue, and live organisms, like osteoblasts, fibroblasts or macrophages. The surrounding ions, biomolecules and live organisms in the tissue will attach to the surface of the implanted material, leading to a change in the chemical environment on the surface of metallic biomaterials and modifying the surface performance of the biomaterial ${ }^{24}$. 
The evaluation of corrosion behavior and other surface properties of biomaterials is generally performed in saline, phosphate buffer saline solution, simulated body fluid containing only inorganic ions, amino acids, proteins and organic acids. Most of them are formulated without examining the influence of characteristic factors in vivo, especially in the presence of cells that also change the local environment on the material's surface. Various types of cells adhere to the metallic surface, and secrete chemical species and biomolecules that alter the corrosion properties of the implant surface. Thus it is not surprising that in vitro test results do not always correlate with processes occurring in the human body.

The in situ corrosion properties of metallic surfaces cultured with living cells, with various cell types, such as osteoblast-like U-2 OS cells ${ }^{25}$, Saos-2 human osteoblasts ${ }^{23}$ and L929 fibroblasts ${ }^{26,27}$, have been scarcely studied in the literature. Hiromoto et el. ${ }^{29}$ established that the corrosion resistance of $316 \mathrm{~L}$ steel decreases with L929 cells. The effect of fibroblast cells on the interface property is the retardation of diffusion through the biomolecule adsorption layer due to the increase in biomolecule density with extracellular matrix consisting with proteins and glycosaminoglycans generated by the cells. Huang ${ }^{28}$ studied polished Ti and Ti-6Al-4V alloy cultured with U-2 OS cells verifying that Ti-based surfaces still showed excellent corrosion resistance in the culture medium during the cell growth period of $72 \mathrm{~h}$ (including the adhesion, spreading, and proliferation stage). Huang ${ }^{28}$ and Garcia-Alonso et. $\mathrm{al}^{23}$ agree that electrochemical impedance spectroscopy is applied successfully to monitor the in situ growing process of osteoblast cells on $\mathrm{Ti}$ and $\mathrm{Ti}-6 \mathrm{Al}-4 \mathrm{~V}$ alloy. To the best of our knowledge, the osteoblast interaction with grown-oxide at lower oxidation temperatures on Ti-based substrates, no performed to date, is of worthwhile interest from the point of view of electrochemical response induced on the substrate surface. 
The main goal of this paper is to analyze the influence of cells on the electrochemical interface and the protectiveness of the grown-oxide at lower oxidation temperatures on Ti. The interaction of cells with the modified surface is studied by electrochemical techniques and XPS. The effect of osteoblast cells on the oxidized Ti surface in the electrochemical system is analyzed in equilibrium (or its zero-current) and when the system is moved from its equilibrium through the application of polarization.

\section{EXPERIMENTAL}

\section{A. Metallic substrates}

Commercial pure titanium disks (Goodfellow, France), $25 \mathrm{~mm}$ diameter and $2 \mathrm{~mm}$ thick were the test specimens. Before oxidation, all major surfaces were successively ground from 400 to 1200 grit with SiC papers in water and polished from $9 \mu \mathrm{m}$ to $1 \mu \mathrm{m}$ alumina solution to obtain a mirror-like finish. The specimens were washed in distilled water and cleaned ultrasonically in ethanol for $10 \mathrm{~min}$. The Ti disks were thermally treated at $277^{\circ} \mathrm{C}$ for $5 \mathrm{~h}$ (hereafter called TT-Ti). The TT-Ti disks were sterilized under UV light for $15 \mathrm{~min}$ before culture experiments.

\section{B. Cells and culture medium}

Human osteosarcoma Saos-2 cells (ECACC, Salisbury, UK) were grown in Dulbecco's Modified Eagle's Medium (DMEM, Gibco Invitrogen GmbH, Germany) that was supplemented with $10 \%(\mathrm{v} / \mathrm{v})$ heat-inactivated fetal bovine serum (FBS), $500 \mathrm{UI} \mathrm{mL}^{-1}$ penicillin, and $0.1 \mathrm{mg} \mathrm{mL}^{-1}$ streptomycin. Cells were maintained in a humidified atmosphere of $95 \%$ air and $5 \% \mathrm{CO} 2$ at $37 \circ \mathrm{C}$. The cell culture medium was changed every 4 days. When the cells reached 80-90\% confluence, a trypsin-EDTA solution (Gibco) was used to detach the cells from the culture flasks. Detached cells were then transferred to the TT-Ti samples at 
a density of $1.5 \times 10^{4}$ cells $\mathrm{cm}^{-2}$. The cell culture medium was changed every 3 days until the end of testing, 7 days. Parallel control tests of osteoblasts on polystyrene culture flasks were carried out to follow the viability of the cell culture.

\section{Experimental techniques}

\section{Characterization techniques}

The topographical information of grown- $\mathrm{TiO}_{2}$ on titanium was recorded by 5100 (Agilent) Atomic Force Microscopy (AFM) equipped with a scanner with maximum ranges of $10 \mathrm{x} 10 \mu \mathrm{m}$ in " $\mathrm{x}$ " and " $\mathrm{y}$ " axis and $4 \mu \mathrm{m}$ in " $\mathrm{z}$ " axis. The images were acquired using silicon nitride cantilevers with a nominal probe curvature radius of $10 \mathrm{~nm}$ and a force constant of $40 \mathrm{~N} / \mathrm{m}$. AFM measurements were performed in tapping mode. Each scan consisted of $512 \times 512$ pixels with WSxM software $(\text { Nanotec })^{28}$.

Scanning Electron Microscopy (SEM) was used to characterize the TT-Ti surfaces before culturing with cells and to verify the good adhesion and morphology of the Saos-2 cells attached to the TT-Ti surfaces after 1, 3, 5, and 7 days.

For SEM analysis, the Saos-2 cell attached on TT-Ti surfaces were fixed in $2.5 \%$ glutaraldehyde in phosphate buffer saline (PBS) solution for $24 \mathrm{~h}$ at $4^{\circ} \mathrm{C}$ and then dehydrated at $4^{\circ} \mathrm{C}$ by using increasing graded ethanol concentrations until reaching $100 \%$ ethanol.

Finally, the cells were dried in successive steps increasing the percentage of tetramethylsylane (TMS) in ethanol. The cell growth on the TT-Ti surfaces was analyzed by using a JEOL-6500F microscope equipped with a field emission gun (FEG) coupled to an energy dispersive X-ray (EDX) spectrometer. The images were taken using secondary electron. 
The chemical composition of the TT-Ti surface without cells and in contact with Saos-2 for 1, 3, 5, and 7 days was performed by X-ray photoelectron spectroscopy (XPS). The cell layers were ultrasonically removed from the surface in distilled water for $10 \mathrm{~min}$ and air-dried ${ }^{29}$. The X-ray photoelectron spectra were recorded using a VG Escalab 200R spectrometer equipped with a hemispherical electron analyzer, operating in a constant pass energy mode $(50 \mathrm{eV})$ and a non-monochromatic $\mathrm{MgK}_{\alpha}\left(\mathrm{h} v=1253.6 \mathrm{eV}, 1 \mathrm{eV}=1.6302 \times 10^{-}\right.$ $\left.{ }^{19} \mathrm{~J}\right)$ at $10 \mathrm{~mA}$ and $12 \mathrm{kV}$. The background pressure in the analysis chamber was kept below $2 \times 10^{-8}$ mbar during data acquisition. XPS data were taken in increments of $0.1 \mathrm{eV}$ with dwell times of $50 \mathrm{~ms}$. Binding energies were calibrated relative to the $\mathrm{C}_{1 \mathrm{~s}}$ peak at $284.9 \pm 0.2 \mathrm{eV}$. High-resolution spectra envelopes were obtained by curve-fitting the synthetic peak components using XPS peak software. The raw data were used with no preliminary smoothing. Symmetric Gaussian-Lorentzian product functions were used to approximate the line shapes of the fitting components. Atomic ratios were computed from the experimental intensity ratios and normalized using atomic sensitivity factors ${ }^{30}$.

\section{Electrochemical techniques}

Electrochemical experiments were performed using an electrochemical cell with a 3electrode setup. A detailed information about the electrochemical cell is given in ${ }^{23,31}$. A platinum wire (99.99\% purity) served as the auxiliary electrode, and all potentials are quoted with respect to the Pt pseudo reference electrode. The area of the working electrode (TT-Ti specimens) was $0.79 \mathrm{~cm}^{2}$ in all the experiments. The electrochemical cell as well as the electrodes were sterilized in an autoclave at $120^{\circ} \mathrm{C}$ for $20 \mathrm{~min}$ before each experiment. The 
electrochemical measurements were performed in cell culture medium (DMEM) and culture medium with cells at $37 \pm 0.5^{\circ} \mathrm{C}$ for $1,3,5$, and 7 days immersion time.

The electrochemical techniques used have been the corrosion potential ( $\left.\mathrm{E}_{\text {corr }}\right)$, Electrochemical Impedance Spectroscopy (EIS) and polarization using a Gamry reference 600 potentiostat.

The EIS experiments were performed at the corrosion potential by applying a sinusoidal wave of very low voltage $( \pm 5 \mathrm{mV})$ in a frequency range from $10^{5} \mathrm{~Hz}$ to $10^{-3} \mathrm{~Hz}$ spaced logarithmically (5 per decade).

The EIS results were analyzed by fitting the experimental impedance data with models of electrical equivalent circuit. The parameters of the electrical equivalent circuit were calculated by fitting the impedance function to the measured spectra using a non-linear least-squares program (NLLS program) with Z-plot/Z-view software for all the measured frequencies. The criteria used to estimate the quality of the fitting were the lowest chi-square value and estimative errors (in \%) for all the components.

Anodic and cathodic polarization curves were recorded at a scan rate of $1 \mathrm{mV} \mathrm{s}^{-1}$ from the corrosion potential to $\pm 0.5 \mathrm{~V}$ with respect to $\mathrm{E}_{\text {corr }}$. A different TT-Ti sample was used for every anodic and cathodic polarization curve. The parameters analyzed were the anodic and cathodic Tafel slopes, $\beta_{\mathrm{a}}$ and $\beta_{\mathrm{c}}$ respectively.

\section{RESULTS AND DISCUSSION}

\section{A. Characterization of the metallic surfaces}

The surface morphology of the thermally treated Ti was examined by SEM and AFM, and the composition after the surface treatment was analyzed by XPS. Figure 1a shows the 
secondary electron image (SEI) of the Ti surfaces after oxidation at $277^{\circ} \mathrm{C}$ for $5 \mathrm{~h}$ (TT-Ti).

The metallic surface shows parallel grooves, typical of the grinding process, in the homogeneous, roughened oxidized surface on which white spots have grown. The white spots are an accumulation of $\mathrm{TiO}_{2}$, as could be verified by EDX (data not shown). The surface roughness (RMS) ranged between 19.43 and $92.40 \mathrm{~nm}$. Figure $1 \mathrm{~b}$ shows an AFM image $(10 \mu \mathrm{m} \times 10 \mu \mathrm{m})$ of the typical grooves that appear on the TT-Ti surface, of about 200 $\mathrm{nm}$ deep and $2 \mu \mathrm{m}$ wide. 


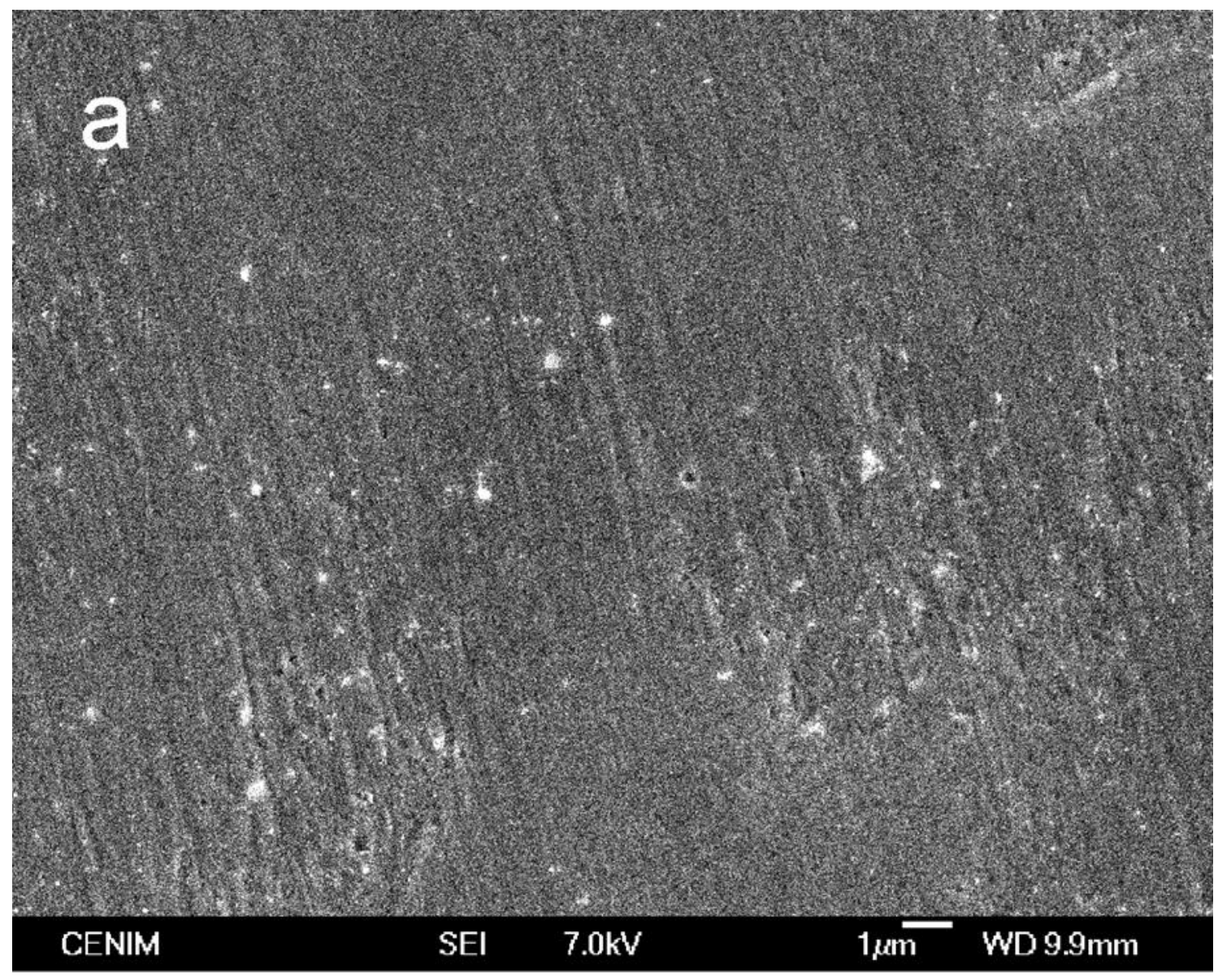

\section{b}
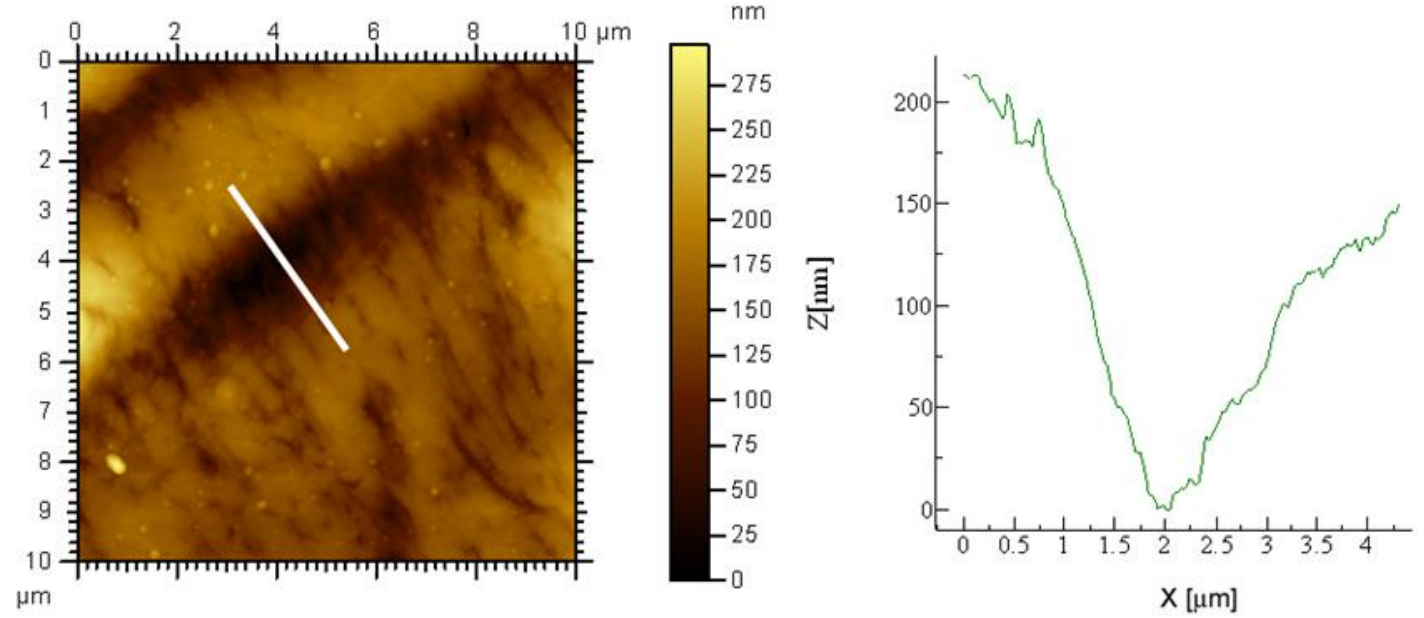

FIG. 1. SEM image (a) and AFM image with height profile (b), of Ti thermally treated at $277^{\circ} \mathrm{C}$ for 5 hours (TT-Ti). 
Svanborg et $a l^{32}$ observed that a commercial implant that was smooth on the micrometer level was not necessarily smooth on the nanometer level. The variation in roughness at the nanoscale level can influence the physical, chemical and biological responses and the in vivo corrosion behavior of the material. Studies have shown that surface nano roughness is important for the osseointegration response. Webster ${ }^{33}$ and Mendonca ${ }^{34}$ demonstrated that nanostructures govern the attachment of proteins to a surface, increasing the adherent cell response in cell cultures that are grown on nanostructure surfaces. Topographical modifications of the surface modulate cellular activities such as adhesion, migration and proliferation. D. Franco et al. ${ }^{35}$ have demonstrated that the geometrical shape characteristics of the patterned area have the potential to modulate cell separation. Goreham et $a l^{36}$ observed that there is a specific nanotopography scale that encourages cell adhesion and spreading, however, the preferential lateral spacing and height of the nanotopography is different for different cell types. After a critical nanoparticle density is reached (higher than $68 \mathrm{~nm})$, the number of adhered cells decreases and at the highest nanoparticle density the cell numbers are similar to these on a smooth surface. Both cell types adhered in lower numbers when the nanotopography feature size increased to $68 \mathrm{~nm}$. They establish that the surface nanotopography affects integrin binding cites orientation and clustering but also suggest that the cell membrane rigidity and the flexibility of cell adhesion machinery, which may be different for varying cell types, is another factor that may need to be taken into consideration.

Khung et al. ${ }^{37}$ used continuous porous silicon gradients to establish the effects of substrate pore size on cell viability and morphology. On the large pores $(1000-3000 \mathrm{~nm})$, cells were unable to adhere optimally on surfaces, but could stabilize themselves through 
cell-cell contacts, reducing the need for cell-substratum contact. Their results revealed that cells were sensitive to nanoscale surface topography with feature sizes of $<20 \mathrm{~nm}$. Yim et al. ${ }^{38}$ conclude that both nanotopography and substrate stiffness could be important in determining mechanical properties, while nanotopography may be more dominant in determining the organization of the cytoskeleton and focal adhesions.

The chemical composition of the TT-Ti surfaces by XPS is shown in Table I, where is summarized the binding energy of the XPS peaks and atomic percentage.

\begin{tabular}{|c|c|c|c|c|}
\hline & Element & Assignation & $\begin{array}{c}\text { Binding } \\
\text { energy, eV }\end{array}$ & Atomic \% \\
\hline \multirow{3}{*}{$*$} & $\mathrm{C}_{1 \mathrm{~s}}$ & $\mathrm{C}-\mathrm{C}, \mathrm{C}-\mathrm{H}$ & 284,8 & 3,5 \\
\cline { 2 - 5 } & $\mathrm{O}_{1 \mathrm{~s}}$ & $\mathrm{TiO}_{2}$ & 529,9 & 58,2 \\
& $\mathrm{Ti}_{2 \mathrm{p}}$ & $\mathrm{TiO}_{2}$ & 458,6 & 14,8 \\
\cline { 2 - 5 } & $\mathrm{Ti}_{2}$ & 531,4 & 23,5 \\
\hline
\end{tabular}

Table I. XPS binding energies for the different peak components of thermally treated titanium surface (TT-Ti).

High resolution XPS of the $\mathrm{Ti}_{2 \mathrm{p}}$ signal confirmed that the chemical composition of the oxide film was $\mathrm{TiO}_{2}\left(\mathrm{Ti}_{2 \mathrm{p} 3 / 2} 458.6 \mathrm{eV} \text { in Table } \mathrm{I}\right)^{39}$. Browne et al ${ }^{40}$ suggested that this $\mathrm{TiO}_{2}$ corresponded to the anatase form, as analyzed by TEM. Controversial results have been found about the best osteoblast cell compatibility depending on the crystal phase. Some authors found that rutile showed higher in vitro osteoblast cell compatibility than anatase structure $^{41,42}$. Conversely, Uchida et $_{a l} \mathrm{l}^{43}$ established that the anatase phase of titania is effective in apatite formation, whereas $\mathrm{Wu}$ et al. demonstrated the bioactive independency of the fraction of anatase and rutile over metal titanium surface to induce deposition of apatite in Kokubo's simulated body fluid ${ }^{44}$.

The high resolution $\mathrm{O}_{1 \mathrm{~s}}$ spectrum shows the separation of the $\mathrm{O}_{1 \mathrm{~s}}$ band into two components: $\mathrm{TiO}_{2}(529.9 \mathrm{eV})$ and $\mathrm{Ti}-\mathrm{OH}(531.4 \mathrm{eV})$ in Table I. These results are consistent 
with those of other groups ${ }^{45}$; thus, the presence of the $-\mathrm{OH}$ group on the surface is ensured with this oxidation treatment.

Based on our characterization, the chemical composition of the TT-Ti surface is mainly $\mathrm{TiO}_{2}$ in anatase-rich titanium dioxide with a low percentage of $\mathrm{OH}$ concentration on titanium substrate with a mean nanorroughness that could promote good cell adhesion. These parameters seems to be adequate to promote a good adhesion.

\section{B. Electrochemical characterization of Saos-2/TT-Ti interface}

Figure 2 shows the evolution of the corrosion potential $\left(\mathrm{E}_{\text {corr }}\right)$ versus time for TT-Ti samples immersed in DMEM without and with Saos-2 over time.

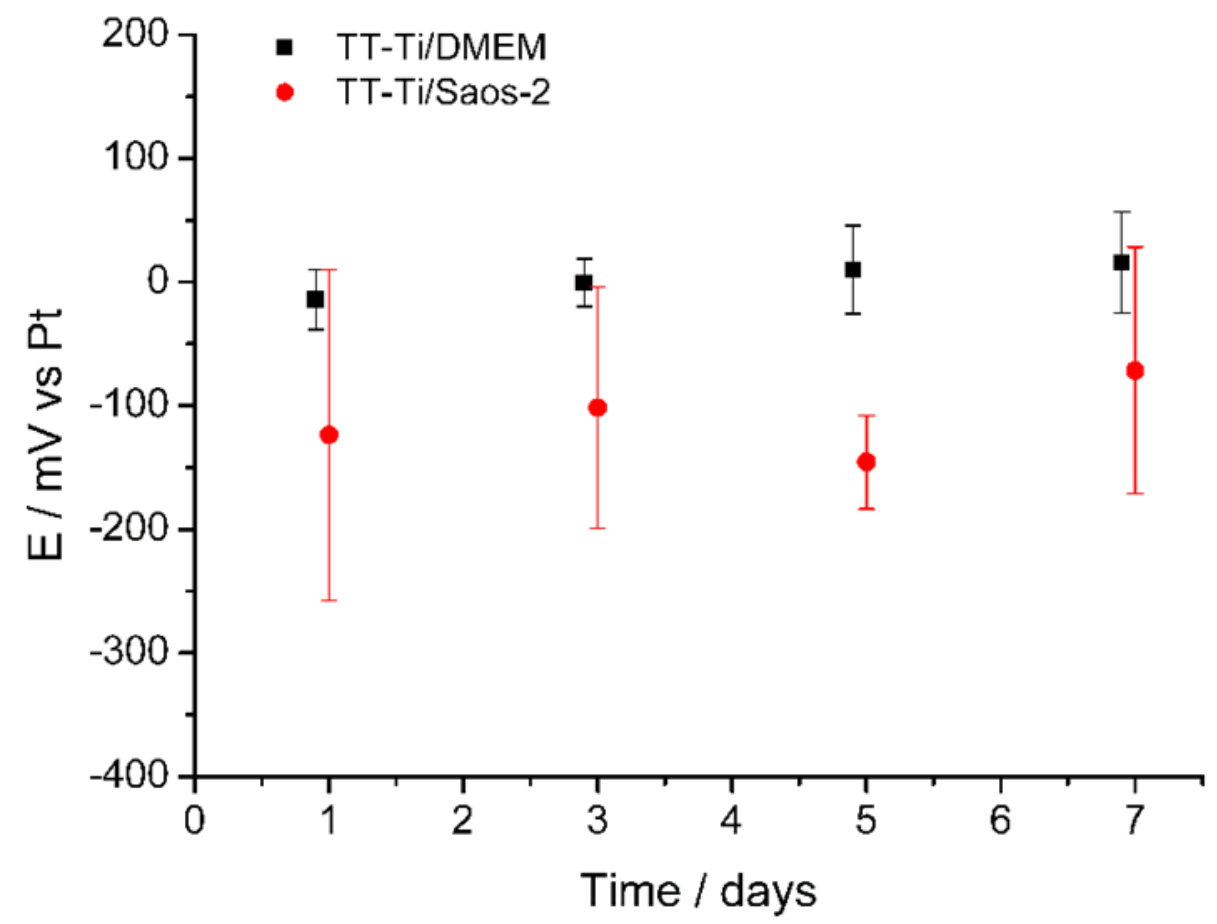

FIG. 2. Corrosion potential, $\mathrm{E}_{\text {corr }}$, vs Time of TT-Ti samples in DMEM/ (घ) and with Saos-2 $(\bullet)$. 
The corrosion potential values change from a stable value around $0 \mathrm{mV}$ in DMEM solution from the beginning to the end of test to around $-100 \mathrm{mV}$ when Saos- 2 cells are present in the corrosive medium. It is interesting to remark the high fluctuation in the corrosion potential values for every immersion time due to the presence of Saos-2. This variability in $\mathrm{E}_{\text {corr }}$ is consistent with other reports ${ }^{23}$.

Aquí

Figure 3 shows the impedance modulus and shift-phase angle versus frequency for TT-Ti specimens over immersion time in DMEM with Saos-2 for 1, 3, 5 and 7 days and without Saos-2 (0 days). For all testing times at the highest frequencies, the impedance modulus exhibits a plateau corresponding to the electrolyte resistance $\left(R_{e}\right)$. Cells are scarcely present on the TT-Ti surfaces after the first day of testing, as can be seen in the topographic image obtained by SEM (Figure 4a).

Impedance plots for the first day of testing of TT-Ti specimens in the presence of Saos-2 are very similar to those recorded for the reference (TT-Ti/DMEM without cells) (Figure 3a), except that the phase angle increases from $-86^{\circ}$ to about $-80^{\circ}$ in the presence of cells in a frequency range of $10^{-1}-10^{-3} \mathrm{~Hz}$ (Figure $3 \mathrm{~b}$ ). In the absence of cells (day 0 ) the system is defined by a single time constant $\tau_{1}=\mathrm{CPE} 1 \cdot \mathrm{R} 1$. However, when cells are present, and from the third day of testing, two slopes appear in the impedance modulus which are assigned to two time constants $\tau_{1}=\mathrm{CPE} 1 \cdot \mathrm{R} 1$ and $\tau_{2}=\mathrm{CPE} 2 \cdot \mathrm{R} 2$. This is better seen in the Bode angle diagram which shows a minimum (at $10^{-2} \mathrm{~Hz}$ frequency) around $-58^{\circ}$ whose value subsequently rises to around $-50^{\circ}$ (Figure $3 \mathrm{~b}$ ). This change in the impedance plots is due to the presence of cells on the TT-Ti surfaces, as can be seen by SEM after three days of testing (Figure $4 \mathrm{~b}-\mathrm{d})$. At $7^{\text {th }}$ day the SEM image (Figure 4d) shows an almost confluent cell 
culture, with small regions of the surface that are without cells but coated with extracellular matrix.
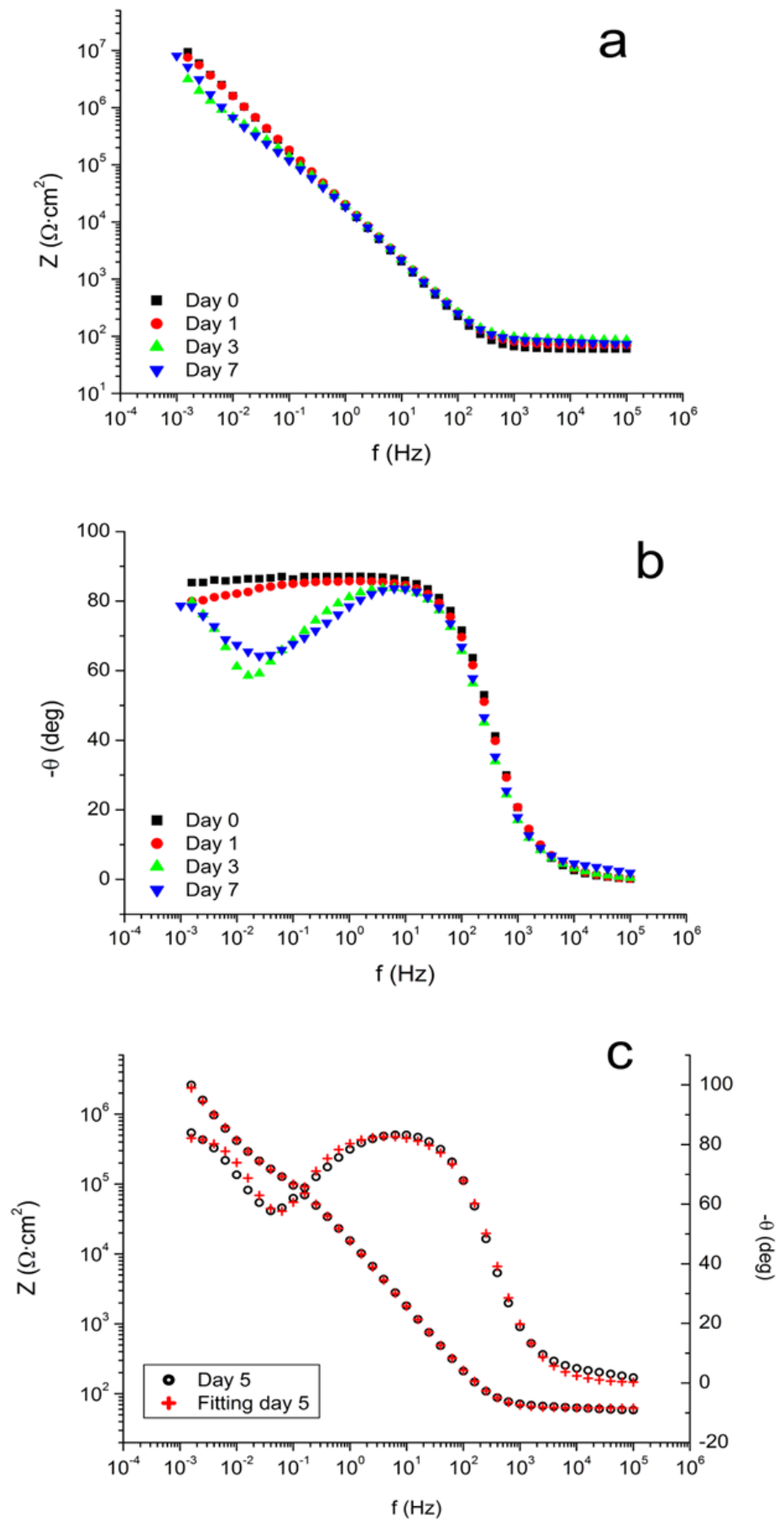
FIG. 3. Impedance modulus (a) and phase angle (b) of Bode diagrams versus frequency of Saos-2/TT-Ti interface at: $\mathbf{}$ ) 0 days (without Saos-2), •) 1 day, $\mathbf{\Delta}) 3$ days and $\boldsymbol{\nabla}$ ) 7 days. c) Impedance modulus of Bode diagrams versus frequency of Saos-2/TT-Ti interface at 5 days (O) and fitting (+).

To examine these changes in the impedance diagrams for TT-Ti specimens, the electrical equivalent circuit models included in Figure 5 have been considered. When cells are not present, the system can be represented by CPE1 and R1 in parallel (Figure 5a), where $\mathrm{CPE} 1$ is the constant phase element simulating a non-ideal behavior of the capacitor due to the interface formed by the corrosive culture medium and the amino acids, proteins, and the oxide layer on the TT-Ti surface; and R1 is associated with the resistance of the modified oxide surface modified by DMEM.

FIG. 4. SEM images of Saos-2 on the TT-Ti surface at: 1 day (a), 3 days (b), 5 days (c) and 7 days (d) of immersion.
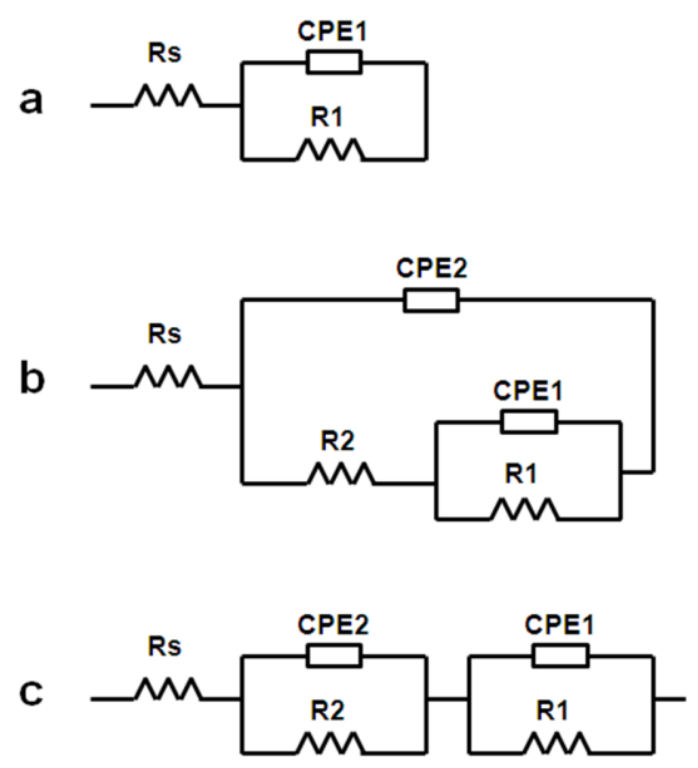

FIG. 5. Equivalent electrical circuits used for fitting the results obtained in impedance diagrams for the Saos-2/TT-Ti system.

In the presence of cells, a new interface is created in addition to the existing one, in which the cell contribution is given by CPE2 and R2 (Figure 5b), where CPE2 is a constantphase element that can be assigned to the capacitance of the protein-containing biomolecule adsorption layer and the presence of the cells, and R2 is the resistance that is associated with it. At $7^{\text {th }}$ day, considering that cell culture became almost confluent, as shown by SEM (Figure 4d), the equivalent circuit of Figure $5 \mathrm{c}$ was used with the same electrochemical elements as $3^{\text {rd }}$ and $5^{\text {th }}$ days but in a different arrangement. 
Table II shows the fitting results for EIS experiments after 0 days (without Saos-2) and after 1, 3, 5 and 7 days of immersion in the presence of Saos-2. As an example, Figure $3 \mathrm{c}$ shows the experimental and the fitting results for the 5th day of testing. Good agreement can be seen between both graphs.

\begin{tabular}{|c|cccccccc|}
\hline Time & Rs & R2 & CPE2 & $\mathrm{n} 2$ & $\mathrm{R} 1$ & $\mathrm{CPE} 1$ & $\mathrm{n} 1$ & $\chi^{2}$ \\
days & $\Omega$ & $\Omega \mathrm{cm}^{2}$ & $\mu \mathrm{Ss}^{\mathrm{n}} \cdot \mathrm{cm}^{-2}$ & & $\Omega \mathrm{cm}^{2}$ & $\mu \mathrm{Ss}^{\mathrm{n}} \cdot \mathrm{cm}^{-2}$ & & \\
& & & & & & & & \\
\hline 0 & 76.3 & - & - & - & $2.2 \cdot 10^{8}$ & 9.05 & 0.968 & $9.8 \cdot 10^{-4}$ \\
1 & 71.8 & $2.4 \cdot 10^{7}$ & 8.56 & 0.954 & $4.3 \cdot 10^{8}$ & 2.94 & 1.000 & $1.9 \cdot 10^{-3}$ \\
3 & 88.0 & $4.2 \cdot 10^{5}$ & 11.85 & 0.941 & $1.1 \cdot 10^{8}$ & 16.84 & 0.888 & $6.5 \cdot 10^{-3}$ \\
5 & 79.0 & $2.1 \cdot 10^{5}$ & 11.56 & 0.939 & $7.2 \cdot 10^{7}$ & 23.42 & 0.966 & $8.4 \cdot 10^{-3}$ \\
7 & 78.4 & $9.5 \cdot 10^{4}$ & 20.67 & 0.914 & $2.1 \cdot 10^{7}$ & 28.65 & 1.000 & $3.5 \cdot 10^{-2}$ \\
\hline
\end{tabular}

Table II. Fitting results obtained from the simulation of the impedance diagrams by using equivalent circuits of figure 5, of Saos-2/TT-Ti interface at $0,1,3$ and 7 days of immersion time.

According to the fit impedance results (Table II), the resistance R2 decreased and the pseudo capacitance (CPE2) of the biomolecule adsorption layer that integrated with Saos-2 cells increased with incubation time, suggesting that the amount of proteins that adsorbed directly onto TT-Ti decreased during the adhesion of Saos-2 cells (i.e., the cells rearrange the adsorbed proteins around them to adhere to titanium, possibly decreasing the amount of proteins that is adsorbed directly by titanium $)^{29}$. The oxide resistance R 1 decreases and CPE1 increases with the testing time. In fact, the greatest variation in $\mathrm{R} 1$ is found for the $7^{\text {th }}$ day of testing (Table II), where it has decreased by almost one order of magnitude, showing that the oxide layer is finer or more permeable. This result indicates that the compounds that are 
generated by Saos- 2 can modify the oxide film, accelerating the dissolution of TT-Ti surfaces. The approximate CPE1 values were $1-2 \times 10^{-5} \mathrm{~F} \bullet \mathrm{cm}^{-2}$ the same magnitude as the capacitance of the adsorbed albumin, fibrinogen, and thrombin to platinum $\left(1-10 \times 10^{-5}\right)$ $\mathrm{F} \cdot \mathrm{cm}^{-2} 46,47,48$.

In the presence of cells, the electrochemical modifications produced in the system moved from equilibrium were also evaluated by applying greater perturbations in order to assess the anodic and cathodic behavior involved in the corrosion process on TT-Ti/Saos-2 interface. Figure 6 shows polarization curves for TT-Ti specimens with and without Saos-2 after 7 days of testing. It can be seen how the anodic current density value rises by approximately one order of magnitude on the surfaces with cells compared to those without cells.

Figure 7 shows the evolution of polarization curves for TT-Ti surfaces with Saos-2 cells after 1,3,5 and 7 days of immersion. As the presence of the cells becomes greater on the TT-Ti surface (Figure 4c-d), the anodic current density rises (Table III). These higher values mean that the charge transfer phenomenon is less impeded on the surfaces with cells due to the less protective nature of the $\mathrm{TiO}_{2}$ layer.

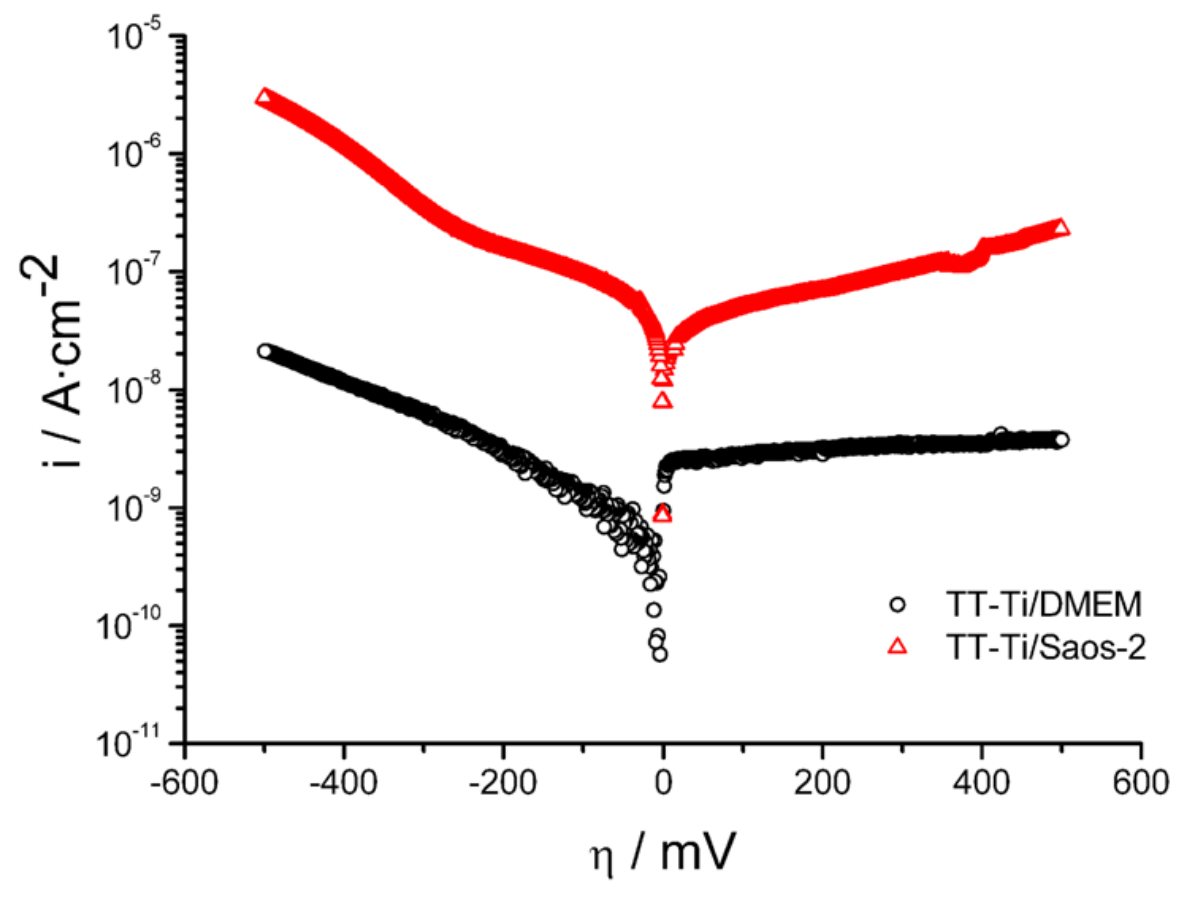


FIG. 6. Polarization curves of DMEM/TT-Ti (o) and Saos-2/TT-Ti $(\Delta)$ after 7 days of immersion.

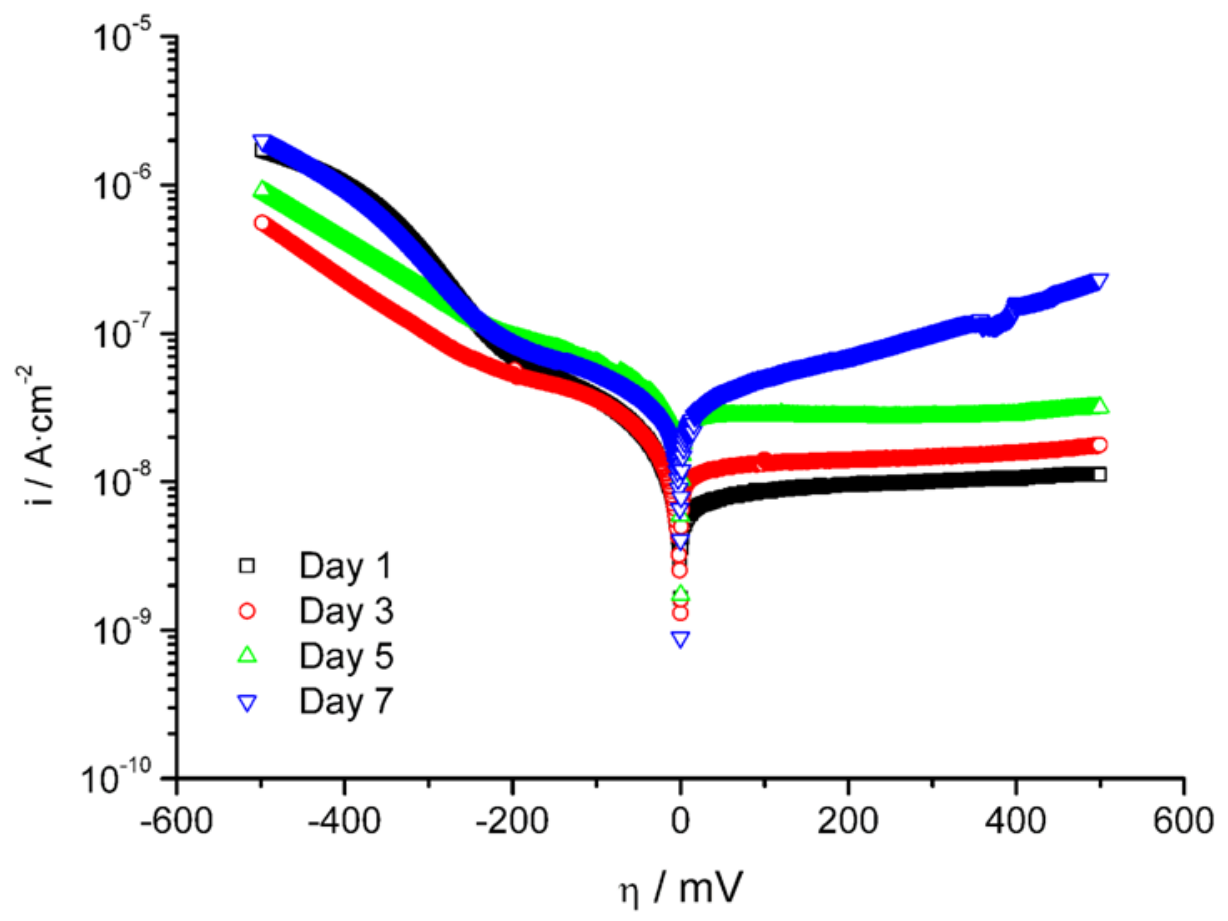

FIG. 7. Polarization curves of Saos-2/TT-Ti interface for $\square$ ) 1 day, O) 3 days, $\Delta) 5$ days and V) 7 days of immersion time.

In Figure 7 (Table III), anodic control of the system can also be seen for the first day of testing $(\beta \mathrm{a}>\beta \mathrm{c})$, which means that the $\mathrm{TiO}_{2}$ layer impedes or delays the charge transfer reaction. However, on the third day of testing (greater presence of cells Figure 4b) the system presents mixed control $(\beta c \approx \beta a)$ and from the $5^{\text {th }}$ day (Figure $\left.4 c-d\right)$ the system is cathodically controlled $(\beta c>\beta a)$, i.e. the access of $\mathrm{O}_{2}$ to the TT-Ti surface controls the corrosion rate of the system, and the protective capacity of the $\mathrm{TiO}_{2}$ layer has decreased or the access of oxygen to the metallic surface/cells interphase is impeded.

The passive current density of Ti increases over incubation time, so the presence of osteoblasts impaired the protectiveness of passive films. This finding indicates that the 
compounds generated by Saos- 2 modified the oxide layer to some degree and accelerated the dissolution of the TT-Ti surfaces. It should be noted that the cells are very reactive, producing superoxides, nitrous oxide and protons, causing direct chemical reactions on the surface $^{25}$. Hiromoto et al ${ }^{49}$ attributed the decrease of protectiveness of passive films to acidification by the accumulated dissolved metal ions (cations) near cells under the diffusion limited environment indicated by cathodic polarization behavior. The accumulation of dissolved metal ions around the implanted metallic materials was reported by Uo et al. ${ }^{50}$ indicating that the $\mathrm{pH}$ of the body fluid around the implanted material is kept lower than the constant $\mathrm{pH}$ around neutral.

In any case, the curves indicate that the cells altered the overall resistance of the TTTi surfaces by increasing the current, probably due to the influence of the lower $\mathrm{pH}$, metabolism products and the effect of some amino acids ${ }^{51}$. This result is in agreement with other works where the dissolution of titanium was enhanced with amino acids and proteins in long-term immersions ${ }^{52}$ and the presence of cells increased the corrosion rate of metallic biomaterials ${ }^{53}$.

\begin{tabular}{|l|l|l|l|}
\hline Time / days & $\beta c / \mathrm{V}$ & $\beta \mathrm{a} / \mathrm{V}$ & $\mathrm{i}_{\text {pas }} / \mathrm{A} \cdot \mathrm{cm}^{-2}\left(\mathrm{x} 10^{-8}\right)$ \\
\hline 1 & 0.354 & 0.715 & 0.95 \\
3 & 0.639 & 0.652 & 1.48 \\
5 & 0.562 & 0.470 & 2.86 \\
7 & 0.511 & 0.387 & 7.58 \\
\hline
\end{tabular}

Table III. Anodic and cathodic Tafel slopes and $i_{\text {pasivation }}$ from polarization curves of TT-Ti samples that have been in contact with Saos-2 culture for 1, 3, 5 and 7 days of immersion.

\section{Characterization of Saos-2/TT-Ti interface}


The surface composition of the oxide layer on TT-Ti that has been in contact with osteoblast cells was analyzed by XPS. This surface characterization seeks to study in depth the interactions between TT-Ti and biological environments in order to try to understand implant-tissue interactions.

The elemental and chemical composition by XPS of Saos-2/TT-Ti interface is shown in Table III and more representative XPS spectra for Ti2p, O1s and C1s are shown in Figure $8 \mathrm{a}, \mathrm{b}$ and $\mathrm{c}$.

\begin{tabular}{|c|c|c|c|c|c|c|c|}
\hline & Element & Assignation & $\begin{array}{c}\text { Binding } \\
\text { energy, eV }\end{array}$ & \multicolumn{4}{|c|}{ Atomic \% } \\
\hline & & & & \multicolumn{4}{|c|}{ Time, 7 days } \\
\hline & $\mathrm{C}_{1 \mathrm{~s}}$ & $\mathrm{C}-\mathrm{C}, \mathrm{C}-\mathrm{H}$ & 284,8 & \multicolumn{4}{|c|}{19,6} \\
\hline & & $\mathrm{C}-\mathrm{NH}-, \mathrm{C}-\mathrm{O}$ & 286,4 & \multicolumn{4}{|c|}{15,0} \\
\hline & & $\mathrm{CO}-\mathrm{NH}-, \mathrm{COOH}$ & 288,3 & \multicolumn{4}{|c|}{11,4} \\
\hline 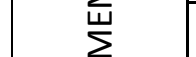 & $\mathrm{O}_{1 \mathrm{~s}}$ & $\mathrm{~N}-\mathrm{C}=\mathrm{O}$ & 531,5 & \multicolumn{4}{|c|}{25,0} \\
\hline 0 & & $\mathrm{C}-\mathrm{O}$ & 533,0 & \multicolumn{4}{|c|}{9,0} \\
\hline$\stackrel{・}{亡}$ & $\mathrm{~N}_{1 \mathrm{~s}}$ & $-\mathrm{O}=\mathrm{C}-\mathrm{NH}-,-\mathrm{NH}_{2}$ & 399,9 & \multicolumn{4}{|c|}{7,4} \\
\hline$F$ & & $-\mathrm{NH}_{3}$ & 401,5 & \multicolumn{4}{|c|}{2,6} \\
\hline & $P_{2 p}$ & $\mathrm{PO}_{4}^{3-}$ & 133,5 & \multicolumn{4}{|c|}{7,0} \\
\hline & $\mathrm{Ca}_{2 \mathrm{p} 3 / 2}$ & $\mathrm{Ca}^{+2}$ & 347,7 & \multicolumn{4}{|c|}{3,0} \\
\hline & & & & \multicolumn{4}{|c|}{ Time, days } \\
\hline & & & & 1 & 3 & 5 & 7 \\
\hline$->\backsim \pi$ & $\mathrm{C}_{1 \mathrm{~s}}$ & $\mathrm{C}-\mathrm{C}, \mathrm{C}-\mathrm{H}$ & 284,8 & 16,7 & 13,5 & 20,7 & 21,8 \\
\hline
\end{tabular}




\begin{tabular}{|c|c|c|c|c|c|c|c|}
\hline & $\mathrm{C}-\mathrm{NH}-, \mathrm{C}-\mathrm{O}$ & 286,2 & 30,7 & 34,3 & 26,7 & 31,8 \\
& $\mathrm{CO}-\mathrm{NH}-, \mathrm{COOH}$ & 288,2 & 20,5 & 17,2 & 18,3 & 19.6 \\
\cline { 2 - 7 } & $\mathrm{TiO}_{2}$ & 529,9 & 4,1 & 4,2 & 4,5 & 2,0 \\
& $\mathrm{~N}-\mathrm{C}=\mathrm{O}$ & 531,6 & 4,2 & 4,1 & 4,0 & 3,5 \\
& $\mathrm{C}-\mathrm{O}$ & 532,8 & 1,3 & 1,8 & 1,5 & 1,9 \\
& & 400,1 & 11,9 & 12,4 & 12,5 & 12,0 \\
& $\mathrm{~N}_{1 \mathrm{~s}}$ & $\mathrm{O}=\mathrm{C}-\mathrm{NH},-\mathrm{NH}_{2}$ & 401,6 & 2,8 & 2,9 & 3,3 & 3,2 \\
\hline & $-\mathrm{NH}_{3}$ & 458,6 & 7,3 & 7,9 & 7,8 & 3,6 \\
\cline { 2 - 7 } & $\mathrm{TiO}_{2}$ & 133,5 & 0,2 & 1,0 & 0,4 & 0,4 \\
\cline { 2 - 7 } & $\mathrm{PO}_{4}{ }^{3-}$ & 347,4 & 0,3 & 0,7 & 0,3 & 0,2 \\
\hline
\end{tabular}

Table IV. XPS chemical composition of thermally treated titanium (TT-Ti) samples that have been in contact with DMEM for 7 days and Saos-2 for 1, 3, 5 y 7 days of immersion time.

High-resolution XPS analysis of the TT-Ti surface in DMEM solution returned no $\mathrm{Ti}_{2 \mathrm{p}}$ signal, demonstrating that the quantity of adsorbed proteins is so large (larger than the electron mean free path of $\mathrm{Ti}_{2 \mathrm{p}}$ photoelectrons, ca. $3 \mathrm{~nm}$ ) masking the underlying titanium surface.
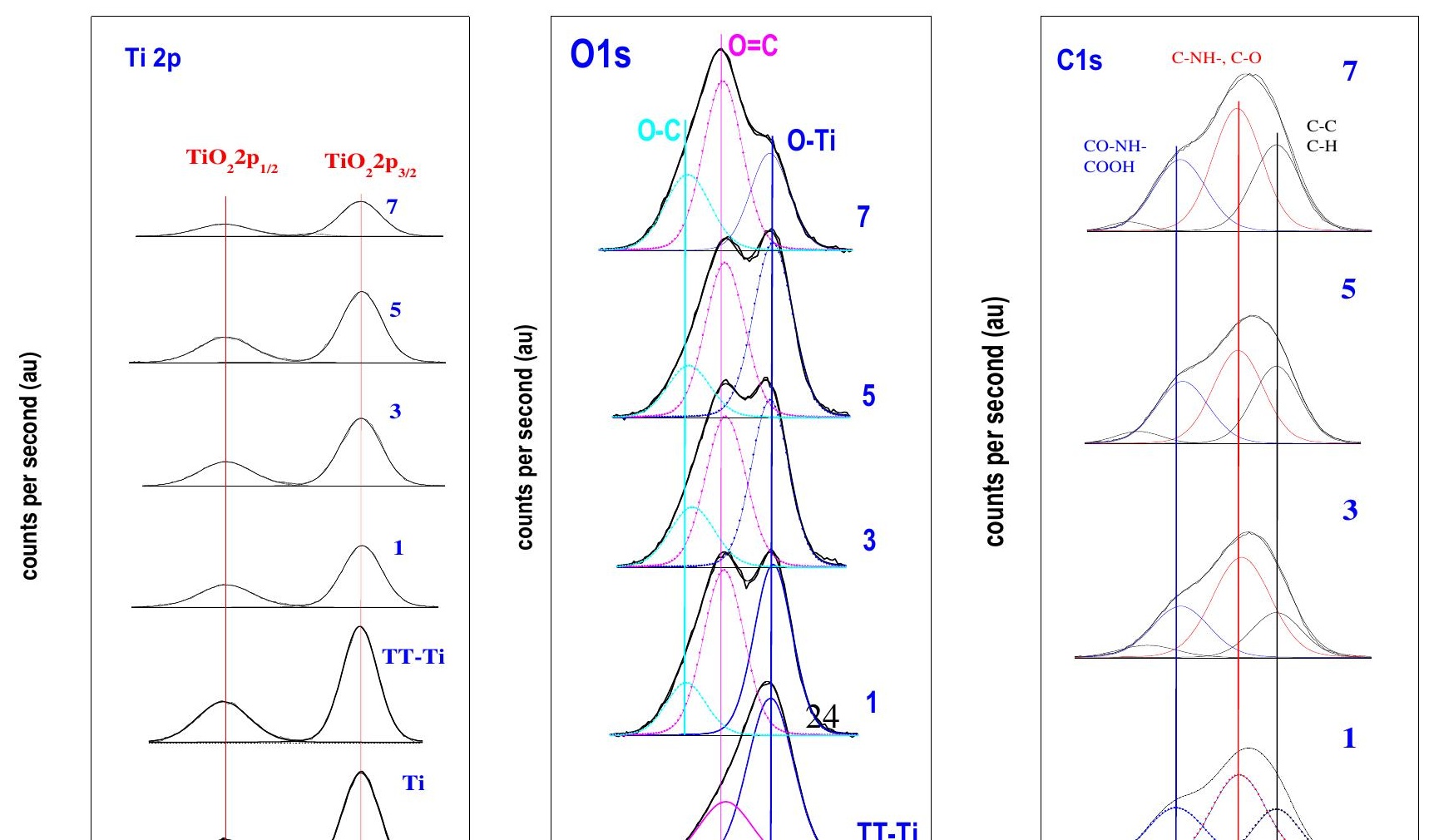
Fig. 8. High-resolution XPS of $\mathrm{Ti}_{2 \mathrm{p}}, \mathrm{O}_{1 \mathrm{~s}}$ and $\left.\left.\mathrm{C}_{1 \mathrm{~s}}, \mathrm{a}\right), \mathrm{b}\right)$ and c), respectively, for TT-Ti and for TT-Ti after being in contact with Saos-2 for 1, 3, 5 and 7 days.

However, the high-resolution $\mathrm{C}_{1 \mathrm{~s}}$ spectrum (data not shown) showed the characteristic bands of the structure of protein (i.e., amino acids arranged in a linear chain and joined together by peptide bonds between the carboxyl and amino groups of adjacent amino acid residues). The deconvolution of the $\mathrm{C}_{1 \mathrm{~s}}$ spectrum results in the following peaks: The first peak, at the lowest binding energy of $284.8 \mathrm{eV}$, was assigned to the carbon that bound to $\mathrm{C}$ or $\mathrm{H}(\mathrm{C}-\mathrm{C}, \mathrm{C}=\mathrm{C}$ and $\mathrm{C}-\mathrm{H}$ groups $)$; the second peak, at $286.3 \mathrm{eV}$, was attributed to the carbon in amine groups (C-NH-) and the C-O single bond; and the third peak, at 288.0 $\mathrm{eV}$, included signals from the peptide bond (CO-NH-) and acidic groups $(\mathrm{COOH})$ (Table IV). Like the $\mathrm{C}_{1 \mathrm{~s}}$ signal, the $\mathrm{N}_{1 \mathrm{~s}}$ band came from adsorbed protein. The $\mathrm{N}_{1 \mathrm{~s}}$ peak was asymmetrical and deconvoluted in two peaks, corresponding to $-\mathrm{NH}^{3+}$ at $401.5 \mathrm{eV}$, and the principal contribution at $399.9 \mathrm{eV}$, corresponding to the peptide bond (-O=C-NH-) and the $\mathrm{NH}_{2}$ group, as expected for amide or amine groups in BSA present in the medium. In fact, the strong adsorption of proteins (BSA) was most likely due to protonated and positively charged amino groups (e.g., histidine, lysine, and arginine). TT-Ti has a negative charge, and positively charged amino groups in proteins act as anchoring sites in the region of contact between the protein and titanium surface. Consistent with these results, the O1s band had the 
following components: $531.2 \mathrm{eV}(\mathrm{C}=\mathrm{O}, \mathrm{O}=\mathrm{C}-\mathrm{OH},-\mathrm{O}=\mathrm{C}-\mathrm{NH}-)$ and $532.6 \mathrm{eV}(\mathrm{C}-\mathrm{OH}, \mathrm{C}=\mathrm{O}$, $\mathrm{COOH})$.

After the DMEM/TT-Ti interface was analyzed by XPS, the evaluation of the surface modification of the TT-Ti as a consequence of the presence of Saos-2 cells (Table IV) is shown. In the presence of cells the $\mathrm{Ti}_{2 \mathrm{p}}$ signal was observed at $458.6 \mathrm{eV}$, which clearly corresponds to $\mathrm{TiO}_{2}$ (Table I). In fact, the $\mathrm{O}_{1 \mathrm{~s}}$ spectrum showed the band corresponding to titanium oxide at the lowest binding energy of $529.9 \mathrm{eV}$ (Figure 8). It should be noted that the atomic percentage decreased at the $7^{\text {th }}$ day but do not disappear (Table I) as happened after 7 days of immersion in DMEM. After 7 days of immersion in DMEM, the protein biofilm covers completely the surface, however, the adhesion mechanisms of the cells is a very dynamic process in which continuous substitution and production of new organic compounds from extracellular matrix give rise, facilitating the presence of free areas on the surface. On the other hand, two reasons can be the responsible of the decrease in the signal coming from the $\mathrm{TiO}_{2}$ layer: the effect of shielding coming from the biofilm of proteins, extracellular matrix and cells that decrease the substrate signal in the XPS spectra; and the loss of thickness of the oxide film due to the corrosive action of the environmental conditions created by cells. The reduction of $\mathrm{TiO}_{2}$ signal after 7 days in contact with the cells agrees with the results obtained from the electrochemical techniques, where the action of cells was revealed along testing time as a decrease in the resistance of the titanium oxide (R1 in Table II), from the EIS tests, the change from anodic ( $1^{\text {st }}$ day) to cathodic (from the $5^{\text {th }}$ day) control of the corrosion mechanism (Table III and Figure 7), and in the increase in the current density (Figure 7) that can be associated with the activation of the surface due to the corrosive compounds generated by the cells. 
On the other hand, in addition to the oxygen in the $\mathrm{TiO}_{2}$ layer, another peak at 531.6 $\mathrm{eV}$ was attributed to oxygen in $\mathrm{N}-\mathrm{C}=\mathrm{O}$ bonds $^{54}$ and a signal at $532.8 \mathrm{eV}$ was assigned to the oxygen atoms that formed single bonds with carbon (Table I).

The oxygen peak may have received contributions from oxygen in carbonate ions, phosphate ions and carboxyl groups ${ }^{32,55}$. The neutral peptide peak at $400.1 \mathrm{eV}$ dominated the $\mathrm{N} 1 \mathrm{~s}$ spectrum with a peak intensity of $80 \%$, and an $-\mathrm{NH}^{3+}$ group at $401.6 \mathrm{eV}$ was observed. The $\mathrm{C}_{1 \mathrm{~s}}$ spectrum was similar to that of TT-Ti in DMEM. Therefore, these well-identified bonds correspond to different chemical groups in proteins such as albumin (BSA).This slight increase is less notable than the reduction in the band due to the $\mathrm{TiO}_{2}$ layer.

XPS data also revealed a peak corresponding to the $\mathrm{P}_{2 \mathrm{p}}$ signal $(133.5 \mathrm{eV})$ and another corresponding to $\mathrm{Ca}_{2 \mathrm{p} 3 / 2}(347.4 \mathrm{eV})$. The presence of $\mathrm{Ca}$ and $\mathrm{P}$ in the analyses, show that these ions, which compete with substances like albumin, are found on the surface layer ${ }^{56,57}$. The $\mathrm{P}_{2 p}$ spectra suggest the presence of phosphorus in phosphate or pyrophosphate compounds $^{32,58} \cdot \mathrm{Ca}_{2 \mathrm{p} 3 / 2}$ spectra have revealed divalent calcium ions ${ }^{32,58}$. Nevertheless, in such short incubation times, this evidence suggests that these ions, which are precursors of hydroxyapatite, were incorporated into the oxide surface at the early stages of contact with Saos-2. This is a very slow but continuous phenomenon.

However, the presence of these ions in the TT-Ti surface over 7 days of contact with Saos- 2 cells was insufficient to induce nucleation of the $\mathrm{Ca} / \mathrm{P}$ precipitate. In fact, the $\mathrm{Ca} / \mathrm{P}$ ratio was low (0.54) compared to the standard value (1.67) for apatite. It is well known that the osseointegration of titanium implants usually takes several months ${ }^{59}$, indicating slow growth. The incorporation of phosphate and calcium ions into the oxide film on titanium has been observed in vivo ${ }^{60}$ and in vitro ${ }^{61}$. 


\section{IV.SUMMARY AND CONCLUSIONS}

- Thermal treatment has yielded a $\mathrm{TiO}_{2}$ layer with surface nano roughness that should promote better cell adhesion to the Ti surface.

- The effect of osteoblast cells on the electrochemical response of TT-Ti was clearly seen from the third day of testing with two time constants that were respectively associated with the presence of Saos-2 cells and the TT-Ti oxide layer. Electrochemical techniques indicate that the cells altered the overall resistance of TT-Ti surfaces, enhancing the anodic current density with time and thus increasing corrosion.

- XPS analysis of TT-Ti after being in contact with osteoblast cells clearly shows the presence of proteins on the surface, as well as a reduction in the thickness and properties of the $\mathrm{TiO}_{2}$ layer due to cell activity. Phosphate and calcium ions were incorporated in the titanium oxide layer after short incubation times.

\section{ACKNOWLEDGMENTS}

The authors are grateful for financial support under project: MAT 2008-06719-C03-01, CTQ2008-05775/BQU and from the Comunidad Autónoma de Madrid (CAM) through AVANSENS S2009/PPQ-1642.

\section{REFERENCES}

\footnotetext{
${ }^{1}$ M.V. Popa, J.M.C. Moreno, M. Popa, E. Vasilescu, P. Drob, C. Vasilescu, S.I. Drob, Surf. Coat. Tech. 205, 4776 (2011).

${ }^{2}$ B. Yang, M. Uchida, H-M. Kim, X. Zhang, T. Kokubo, Biomaterials 25, 1003 (2004).

${ }^{3}$ H. Zreiqat, S.M. Valenzuela, B.B. Nissan, R. Roest, C. Knabe, R.J. Radlanski, Herbert Renz, Peter J Evans. The effect of surface chemistry modification of titanium alloy on signaling pathways in human osteoblasts, Biomaterials 26 (2005) 7579-7586.
} 
${ }^{4}$ M.Rizwan, A. Ahmad, K.M. Deen, W. Haider, Applied Surface Science 320718 (2014).

5 A. Cimpean, E. Vasilescu, P. Drob, I. Cinca, C. Vasilescu, M. Anastasescu, V. Mitran, S. I. Drob, Mater Sci Eng C 38127 (2014).

${ }^{6}$ F.Y. Zhou, B.L. Wang, K.J. Qiu, H.F. Li, L. Li, Y.F. Zheng, Y. Han, Applied Surface Science 265878 (2013).

${ }^{7}$ X. Liu, P.K. Chu, C. Ding, Mater. Sci. Eng., R, 4749 (2004).

${ }^{8}$ D. Liu, K. Savino, M.Z. Yates, Surface \& Coatings Technology 205, 3975 (2011).

${ }^{9}$ K. Cai, M. Lai, W. Yang, R. Hu, R. Xin, Q. Liu, K.L. P. Sung, Acta Biomaterialia 62314 (2010)

${ }^{10}$ R. Bailey, Y. Sun. Pack carburisation of commercially pure titanium with limited oxygen diffusion for improved tribological properties, Surface Coatings Technology 26128 (2015).

${ }^{11}$ W. Yan, X. X. Wang. Surface hardening of titanium by thermal oxidation, J Materials Science 395583 (2004).

${ }^{12}$ Y. Z. Kim, Takashi Konno, Taichi Murakami, Takayuki Narushima and Chiaki Ouchi. Surface hardening treatment for titanium materials using Ar-5\% CO gas in combination with post heat treatment under vacuum. Materials Transactions, 50, 2763 (2009).

${ }^{13}$ D. Siva Rama Krishna, Y.L. Brama, Y. Sun, Tribol. Int. 40, 329 (2006).

${ }^{14}$ A. Bello Samir, I. de Jesus-Maldonado, E. Rosim-Fachini, A. Sundaram Paul, N. Diffoot-Carlo, J Mater Sci Mater Med 21, 1739 (2010).

${ }^{15}$ M.L. Escudero, M.A. Munoz-Morris, M.C. Garcia-Alonso, E. Fernandez-Escalante, Intermetallics, 12, 253 (2004).

${ }^{16}$ L. Saldana, N. Vilaboa, G. Valles, J. Gonzalez-Cabrero, L. Munuera, J. Biomed. Mater.

Res., Part A, 73A, 97 (2005).

${ }^{17}$ M.C. Garcia-Alonso, L. Saldana, G. Valles, J.L. Gonzalez-Carrasco, J. Gonzalez- Cabrero, M.E. Martinez, E. Gil-Garay, L. Munuera, Biomaterials 24, 19 (2003).

${ }^{18}$ M Wen, C Wen, P Hodgson, Y Li. Colloids and Surfaces B: Biointerfaces 116658 (2014).

${ }^{19}$ C. Treves, M. Martinesi, M. Stio, A. Gutierrez, A. Jimenez Jose, F. Lopez Maria, J Biomed Mater Res A 92 , 1623 (2010).

${ }^{20}$ H.T. Chen, C.J. Chung, T.C. Yang, I.P. Chiang, C.H. Tang, K.C. Chen, J.L. He, Osteoblast growth behavior on micro-arc oxidized $\beta$-titanium alloy, Surface Coatings Technology 2051624 (2010).

${ }^{21}$ H-T Chen, C-J Chung, T-C Yang, C-H Tang, J-L Hea. Microscopic observations of osteoblast growth on micro-arc oxidized $\beta$ titanium, Applied Surface Science 26673 (2013).

${ }^{22}$ D.B. Jones, Cells and Metals in Metals as biomaterials (John Wiley and sons, Chichester, England, (1998).

${ }^{23}$ G. Lu, S.L. Bernasek, J. Schwartz, Surf. Sci. 458, 80 (2000).

${ }^{24}$ S. Hiromoto. Corrosion of Metallic Biomaterials in Cell Culture Environments, The Electrochemical Society Interface 41 (Summer 2008). 
${ }^{25}$ H.H. Huang, Biochem Biophys Res Commun. 314, 787 (2004).

${ }^{26}$ S. Hiromoto, K. Noda, T. Hanawa, Electrochim. Acta 48, 387 (2002).

${ }^{27}$ S. Hiromoto and T Hanawa. Electrochemical properties of 316L stainless steel with culturing L929 fibroblasts, J. R. Soc. Interface 3495 (2006).

${ }^{28}$ I. Horcas, R. Fernandez, J.M. Gomez-Rodriguez, J. Colchero, J. Gomez-Herrero, A.M. Baro, Rev Sci Instrum 78, 013705 (2007).

${ }^{29}$ J. Pan, H. Liao, C. Leygraf, D. Thierry, J. Li, J. Biomed. Mater. Res. 40, 244 (1998).

${ }^{30}$ C.D. Wagner, L.E. Davis, M.V. Zeller, J.A. Taylor, R.H. Raymond, L.H. Gale, SIA, Surf. Interface Anal. 3, $211(1981)$.

${ }^{31}$ Alonso C, García-Alonso MC, Escudero ML, Spain Patent No. 200801041 (2008).

${ }^{32}$ L.M. Svanborg, M. Andersson, A. Wennerberg, J. Biomed. Mater. Res., Part B, 92B, 462 (2010).

${ }^{33}$ T.J. Webster, C. Ergun, R.H. Doremus, R.W. Siegel, R. Bizios, Biomaterials 21, 1803 (2000).

${ }^{34}$ G. Mendonca, D.B.S. Mendonca, L.G.P. Simoes, A.L. Araujo, E.R. Leite, W.R.

Duarte, F.J.L. Aragao, L.F. Cooper, Biomaterials 30, 4053 (2009).

${ }^{35}$ D. Franco, M. Klingauf, M. Cecchini, V. Falk, C. Starck, D. Poulikakos, A. Ferrari, Biointerphases 834 (2014).

${ }^{36}$ R.V. Goreham, A. Mierczynska, L.E. Smith, R. Sedev and K. Vasilevet, Small surface nanotopography encourages fibroblast and osteoblast cell adhesion, RSC Adv 3, 10309 (2013).

${ }^{37}$ Y.L. Khung, G. Barritt, N.H. Voelcker. Using continuous porous silicon gradients to study the influence of surface topography on the behaviour of neuroblastoma cells. Experimental Cell Research, 314789 (2008).

${ }^{38}$ E.K.F. Yim, E.M. Darling, K. Kulangara, F. Guilak, K.W. Leong. Nanotopography-induced changes in focal adhesions, cytoskeletal organization, and mechanical properties of human mesenchymal stem cells Biomaterials 311299 (2010).

${ }^{39}$ I. Vaquila, M.C.G. Passeggi, Jr., J. Ferron, Appl. Surf. Sci. 93, 247 (1996).

${ }^{40}$ M. Browne, P.J. Gregson, Biomaterials 15, 894 (1994).

${ }^{41}$ T-C Yang, H-Y Shu, H-T Chen, C-Je Chung, J-L He. Interface between grown osteoblast and micro-arc oxidized bioactive layers, Surface Coatings Technology 259185 (2014).

${ }^{42}$ MC Garcia-Alonso, L Saldaña, C Alonso, V Barranco, MA Muñoz-Morris, ML Escudero. In situ cell culture monitoring on Ti6Al4V surface by electrochemical techniques, Acta Biomaterialia 51374 (2009)

${ }^{43}$ M. Uchida, H-M. Kim, T. Kokubo, S. Fujibayashi, T. Nakamura, J. Biomed. Mater. Res., Part A 64A, 164 (2003).

${ }^{44}$ J. Wu, Z.M. Liu, X.H. Zhao, Y. Gao, J. Hu, B. Gao, Improved biological performance of microarc-oxidized low-modulus Ti-24Nb-4Zr-7.9Sn alloy, Journal of Biomedial Materials Research, Part B 92, 298 (2010).

${ }^{45}$ E. McCafferty, J.P. Wightman, Appl. Surf. Sci. 143, 92 (1999). 
${ }^{46}$ P. Bernabeu, L. Tamisier, A. De Cesare, A. Caprani, Electrochim. Acta 33, 1129 (1988).

${ }^{47}$ F. Lacour, M.M. De Ficquelmont-Loizos, A. Caprani, Electrochim. Acta, 36, 1811 (1991).

${ }^{48}$ B.A. Ivarsson, P.O. Hegg, K.I. Lundstroem, U. Joensson, Colloids Surf. 13, 169 (1985).

${ }^{49} \mathrm{~S}$. Hiromoto and T. Hanawa. $\mathrm{pH}$ near Cells on Stainless Steel and Titanium. Electrochemical and Solid-State Letters, 7 B9-B11 (2004).

${ }^{50}$ M. Uo, F. Watari, A. Yokoyama,H. Matsuno, and T. Kawasaki, Biomaterials 22677 (2001).

${ }^{51}$ T. Hanawa, Y. Kohayama, S. Hiromoto and A. Yamamoto. Effects of Biological Factors on the Repassivation Current of Titanium. Materials Transactions, 451635 (2004).

${ }^{52}$ D.B. B. Alberts, J. Lewis, M. Raff, K. Roberts, J.D. Watson, Molecular Biology of the Cell, 1990.

${ }^{53}$ D. K. R. Messer, G. Austin, R. Venugopalan, Society for Biomaterials 27th Annual. Meeting Transactions, Saint Paul, 2001, pp. 221.

${ }^{54}$ C.M. Pradier, F. Karman, J. Telegdi, E. Kalman, P. Marcus, J. Phys. Chem. B 107, 6766 (2003).

${ }^{55}$ K. Mustafa, J. Pan, J. Wroblewski, C. Leygraf, K. Arvidson, J Biomed Mater Res 59, 655 (2002).

${ }^{56}$ A.I. Munoz, S. Mischler, J. Electrochem. Soc. 154, C562 (2007).

${ }^{57}$ A.P.V.A. Serro, A.C. Fernandes, B. de Jesus, V. Saramago, Colloids Surf. B 10, 95 (1997).

${ }^{58}$ K. Mustafa, J. Pan, J. Wroblewski, C. Leygraf, K. Arvidson, J Biomed Mater Res 59, 655 (2002).

${ }^{59}$ T.O. Albrektsson, C.B. Johansson, L. Sennerby, Periodontology 2000 4, 58 (1994).

${ }^{60}$ J.E. Sundgren, P. Bodoe, I. Lundstroem, J. Colloid Interface Sci. 110, 9 (1986).

${ }^{61}$ T. Hanawa, M. Ota, Biomaterials 12, 767 (1991). 